\title{
SERRATIA MARCESCENS AS A CAUSE OF CERVICAL MYELOPATHY
}

\author{
SERRATIA MARCESCENS COMO CAUSA DE MIELOPATIA CERVICAL \\ SERRATIA MARCESCENS COMO CAUSA DE MIELOPATÍA CERVICAL \\ Mireles Cano José Nicolás, ${ }^{1,2}$ Garcia Gonzalez Oscar Guillermo, ${ }^{1,2}$ Romero Conejo luis Benito, ${ }^{3,4}$ Colin González Christian Gerardo, ${ }^{3,4}$ \\ Reyes Velasco Esteban, ${ }^{3,4}$ Kala-Garcia Linaloe Atenas, ${ }^{3}$ Martinez-Pérez Ricardo ${ }^{5}$ \\ 1. Hospital Regional de Alta Especialidad (HRAEB), Department of Neurosciences, Spinal Surgery Service, León, Guanajuato, Mexico. \\ 2. Universidad de Guanajuato, Department of Medicine, Health Sciences Division, León, Guanajuato, Mexico. \\ 3. Universidad de Guanajuato, Escuela de Medicina, León, Guanajuato, Mexico. \\ 4. Hospital Regional de Alta Especialidad (HRAEB), Spinal Surgery, León, Guanajuato, Mexico. \\ 5. Centenario Hospital Miguel Hidalgo (CHMH), Traumatology and Orthopedics, Aguascalientes, Aguascalientes, Mexico.
}

\begin{abstract}
Introduction: The main causative agent of spinal infections is Mycobacterium Tuberculosis, followed by saprophytes of the skin. The most affected segment is the lumbar, followed by the thoracic. Objective: Case report. Results: A previously healthy 40-year-old man with posterior cervical pain and myelopathy was referred to our spine service for vertebral destruction syndrome in C3-C4 and altered carbohydrate metabolism. Microdiscectomy and abscess drainage were performed and a biopsy was taken for definitive diagnosis. Multiresistant Serratia Marcescens was isolated in the culture. Both the myelopathy and carbohydrate intolerance were resolved as the infection was resolved. Conclusion: The significance of this case lies in the infective presentation of the S. Marcescens in an immunocompetent person, since it is mainly an opportunistic microorganism, and in the atypical location. The most commonly isolated pathogen is Mycobacterium Tuberculosis, followed by Staphylococcus aureus. Identification of the causative agent is essential to the initiation of antibiotic therapy. Therefore, microbiological isolation plays a fundamental role in the treatment, recovery and quality of life of the patient. Level of evidence V; Case report.
\end{abstract}

Keywords: Cervical spondylodiscitis; Serratia Marcescens; Myelopathy.

\section{RESUMO}

Introdução: O principal agente causador das infecções da coluna vertebral é o Mycobacterium tuberculosis, seguido pelos saprófitos da pele. O segmento mais afetado é o lombar, seguido pelo torácico. Objetivo: Relato de caso. Resultados: Um homem, anteriormente saudável, de 40 anos, com dor cervical posterior e mielopatia como principal sintomatologia, foi encaminhado ao nosso serviço de coluna vertebral com síndrome de destruição vertebral em C3-C4 e alteração do metabolismo de carboidratos. A microdiscectomia e a drenagem de abscessos foram realizadas e uma biópsia foi feita para diagnóstico definitivo. A Serratia marcescens multirresistente foi isolada na cultura. Tanto a mielopatia como a intolerância a carboidratos foram resolvidas, uma vez que a infecção foi tratada. Conclusão: A importância desse caso reside na apresentação infecciosa da S. marcescens em uma pessoa imunocompetente, uma vez que esse é principalmente um microrganismo oportunista e por sua localização atípica. O patógeno mais comumente isolado é o Mycobacterium tuberculosis, seguido pelo Staphylococcus aureus. A identificação do agente causador é essencial para início da terapia com antibióticos. Portanto, o isolamento microbiológico desempenha um papel fundamental no tratamento, recuperação e qualidade de vida do paciente. Nível de evidência: V; Relato de caso.

Descritores: Espondilodiscite cervical; Serratia Marcescens; Mielopatia.

\section{RESUMEN}

Introducción: El principal agente causal de las infecciones de columna es la Mycobacterium Tuberculosis seguido de los saprófitos de la piel y el principal segmento afectado es el lumbar, seguido del torácico. Objetivo: Reporte de caso. Resultados: Presentamos un masculino de 40 años previamente sano, referido al servicio de columna por síndrome de destrucción vertebral C3-C4, con dolor cervical posterior y mielopatía como principal sintomatología, y alteración del metabolismo de carbohidratos. Se realizó microdiscectomía y drenaje de absceso con toma de biopsia para diagnóstico definitivo. En el cultivo se aisló Serratia Marcescens, multirresistente. La mielopatía y la intolerancia a los carbohidratos se resolvieron una vez resuelta la infección. Conclusión: La importancia de este caso radica en la presentación infectante de la S. Marcescens en una persona inmunocompetente ya que esta es principalmente un microorganismo oportunista y por su localización atípica. El patógeno más comúnmente aislado es Mycobacterium Tuberculosis seguido de Staphylococcus aureus. La identificación del agente causal es fundamental para iniciar la terapéutica antibiótica. Por lo tanto, el aislamiento microbiológico tiene un papel fundamental en el tratamiento, la recuperación y calidad de vida del paciente. Nivel de evidencia V; Reporte de caso.

Descriptores: Espondilodiscitis cervical; Serratia Marcescens; Mielopatía. 


\section{INTRODUCTION}

The incidence of spondylodiscitis has been increasing ${ }^{1,2}$ over the last 15 years. There are multiple causes, such as the increase in life expectancy, the increase in the incidence of chronic degenerative diseases, the use of intravenous (IV) drugs and improvement in diagnosis

In spontaneous spondylodiscitis, hematogenous contamination is the most frequent cause ${ }^{3,4}$ and mainly affects the lumbar spine, while the cervical region is more often affected among users of IV drugs. Distant foci have been identified in almost half of the cases, the most frequent being genitourinary (17\%), followed by skin and vascular and gastrointestinal accesses. The main risk factor is diabetes mellitus.

The principal causative agent of spinal infections is M. Tuberculosis (9-46\% globally), followed by S. Aureus (50\% of the non-tuberculous cases), and others such as S. Viridans, Pseudomonas aeruginosa, E. Coli, and Klebsiella. The main segment affected is the lumbar, followed by thoracic and cervical regardless of whether the infection is spontaneous or postsurgical. ${ }^{5}$ However, spondylodiscitis from $S$. Marcescens acquired in the community is quite rare since it is an opportunistic microorganism. ${ }^{6,7}$ A rare case of cervical spondylodiscitis due to S. Marcescens was reported in a previously healthy patient, which also caused severe loss of metabolic control and an altered overall condition in the patient and required medical management.

\section{METHODS}

We present here a clinical case with prior written patient authorization via an informed consent form and approved by the institutional review board.

\section{Case report}

A 40-year-old male was referred to our service for vertebral destruction syndrome. During the previous six months he had experienced multi-treated cervicalgia and two months prior to the consultation he sought medical attention at a local hospital for weakness and paresthesia of the lower limbs, so magnetic resonance (MRI) was performed revealing vertebral destruction of C3-C4, C5-C6-C7. He was also diagnosed with diabetes mellitus and treatment with metformin $850 \mathrm{mg}$ every 12 hours was initiated and he was sent to the HRAEB.

At admission the patient was alert, his temperature was $36.5^{\circ} \mathrm{C}$, his blood pressure was $120 / 70 \mathrm{mmHg}$, his heart rate was 87 beats per minute, and his respiratory frequency was 19 breaths per minute. He was diaphoretic with capillary glycaemia of $25 \mathrm{mg} / \mathrm{dl}$ and a bolus of 25 cc of dextrose at $50 \%$ was administered and a $5 \%$ glucose solution was maintained, the oral hypoglycemic agents were suspended and capillary glycaemia monitoring was indicated every 2 hours. He referred to cervical pain, 8/10 on the visual analogue scale (VAS), which increased with movement and decreased when at rest and did not decrease with non-steroidal analgesics. He had lost approximately 10 kilos of weight. In the neurological examination, the patient presented dysesthesias in the lower limbs from L1, strength of 2/5 in the upper limbs and 3/5 in the lower limbs on the Daniels scale with bilateral hyperreflexia of L4 and S1, bilateral Babinski, Asia D, and Frankel D.

Laboratory data showed an increase in the erythrocyte sedimentation rate (ESR) to $40 \mathrm{~mm} / \mathrm{hr}$, C-reactive protein (CRP) of 354, and the rest were normal. The MRI had vertebral destruction data and the glycaemia was difficult to normalize.

A protocol for vertebral destruction was initiated with blood culture, urine culture (both negative), serial laboratory tests including complete blood count, ESR (which remained high at a mean of 40 $\mathrm{mm} / \mathrm{hr}$ ), CRP (mean of 348), and blood chemistry (without changes). Both gastrointestinal and respiratory infections were ruled out. In the cervical MRI with contrast, loss of cervical lordosis with an angle of $-6^{\circ}$ and irregularity in the levels of C3-C4 and C5-C6 were observed. A prevertebral abscess from C2-T1 was observed in the T2 sequence (Figure 1) and in the ubiquicidin-labelled gammagram (Figure 2).

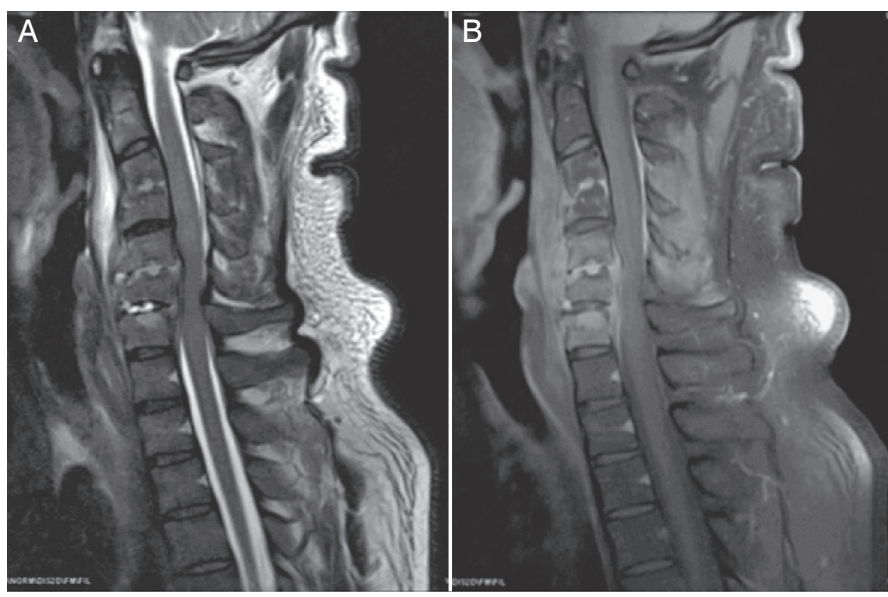

Figure 1. (A) Simple MRI in T2, sagittal cut of the cervical region over the midline where vertebral destruction changes mainly in the C3-C4 and C5-C6 levels are observed with reduction of the cervical spinal canal space. (B) $\mathrm{MRI}$ in T1 with contrast of the cervical region, sagittal cut over the midline where an increase in uptake in the vertebral bodies from C3 to C7, as well as irregularities in their levels, and a paravertebral abscess from C2 to T1 and intraspinal collection with medullary compression are observed.

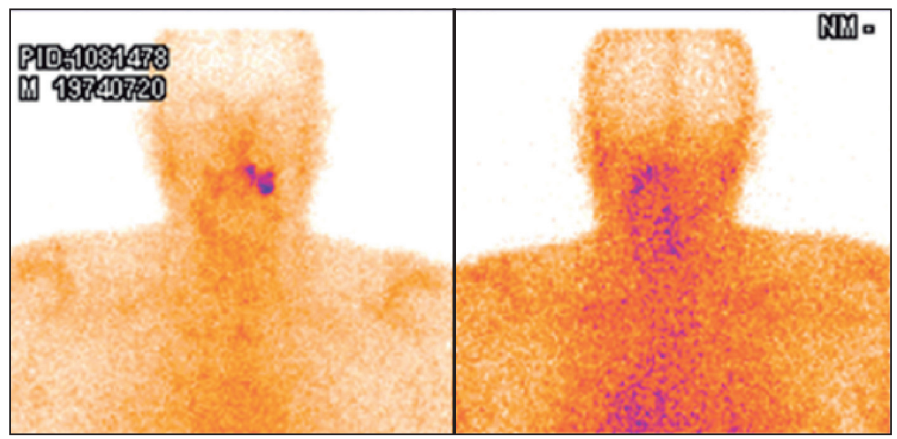

Figure 2. Ubiquicidin-labelled gammagram of the cervical region. Increased uptake of the drug is observed in the cervical region.

Surgical management was proposed to the patient and an informed consent form was signed in which he accepted the proposed treatment. An anterior approach cervical microdiscectomy was performed, the abscess was drained (purulent fluid) from the C5-C6 space, and a biopsy was taken and sent to microbiology for culture and pathology to rule out malignancy. Multiresistant Serratia Marcescens was isolated in the culture and the histopathology results were negative for malignancy. Antibiotic treatment with trimethoprim and sulfamethoxazole for 6 weeks was indicated by infectology. The patient progressed towards improvement. The glycaemia normalized until no further treatment was required, so it was concluded that it was due to the metabolic response to the trauma. The myelopathy reversed progressively and at 12 months the patient was neurologically intact. Consolidation of the vertebral bodies causing fusion of the affected segment was observed in imaging studies (Figure 3), in addition to a loss of lordosis and cervical angle of $-6^{\circ}$ and the spinal cord was without alteration. Instrumentation was proposed to ensure cervical stability, however, the patient did not accept because he was asymptomatic.

\section{DISCUSSION}

The importance of this case lies in the presentation in an immunocompetent patient who, in addition to developing an opportunistic infection, had a strong metabolic response to the trauma, characterized by difficult to control glycemic alterations and was initially categorized as a recently diagnosed diabetic. However, once the infection was resolved, his carbohydrate metabolism normalized. 


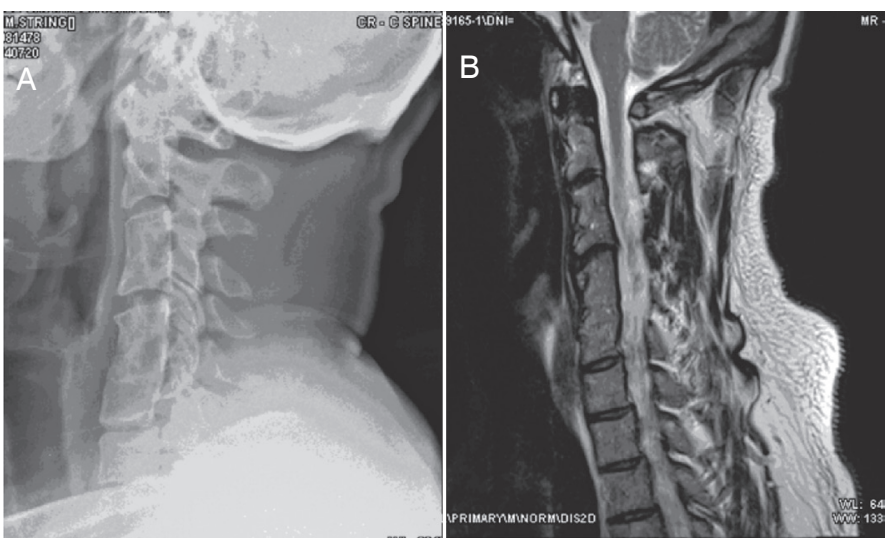

Figure 3. (A) Serratia Marcescens. Lateral cervical radiograph after treatment, with C3-C4 and C5-C6-C7 fusion data and a cervical angle of $-6^{\circ}$. (B) Magnetic resonance in T2 sequence following treatment with no medullary compression.

The patient's myelopathy was resolved by the eliminating the effect of volume by draining the abscess.

The diagnosis and treatment of spondylodiscites is a challenge because the clinical and radiographical presentation is varied and the etiology can be metabolic, neoplastic or, as in this patient, infectious. Obtaining a sample is vital, since imaging studies only show suggestive data but are not diagnostic of etiology.

There is little specific information in the literature about cervical spondylodiscites since they have the lowest incidence ${ }^{8,9}$ at $6 \%-10 \%$. The most affected segment is C5-C6 at 43\%, followed by C6-C7 at $27 \%$, with the least affected segment being C1-C2 at $7 \%$. Lesions extending 3 levels, as in our patient, are the least frequent at 13\%, with monosegmental lesions being the most common in $57 \%$ of cases. The presence of an epidural abscess is greater in cervical infections; $80 \%$ in the 2012 Shousha and Boehm series, however, Heyde el al. ${ }^{10}$ reported a low incidence of this phenomenon at $39 \%$.

The main problem lies in the location of these infections, since they can have a much more dramatic outcome than those located in other spinal segments. The most serious cases can present progressive neurological deterioration (40\%), sepsis, and life-threatening myelopathy (high levels). However, as in this patient, the literature reports that in most spondylodiscites the main and often only symptom is cervicalgia, which can lead to erroneous diagnoses and treatments, especially in patients without risk factors as in the case presented.

As in other forms of spondylodiscitis, it usually occurs during two age ranges: under twenty and between 50 and 70 years of age. As already mentioned, Serratia Marcescens is not among the usual pathogens. The most common pathogen in pyogenic spinal infections is Staphylococcus aureus (20-84\%). S. Marcescens is an opportunistic aerobic gram negative bacillus recognized as a nosocomial pathogen that becomes infectious when the immunity of the host is compromised (with HIV, diabetes mellitus, in chemo/ radiotherapy) and in IV drug users, but non-infectious in immunocompetent patients without associated risk factors (acupuncture or previous surgery), with a predilection for the central nervous system in the postoperative period. ${ }^{11}$

Identification of the causal agent is essential to adjust antibiotic therapy because the empirical antibiotic administered may not be adequate and would make the condition chronic. This is the first case of spondylodiscitis from $S$ Marcescens in its infectious form in an immunocompetent patient without a history of cervical spinal surgery. Centeno et al. describe a similar case located in the sacroiliac of a healthy patient, ${ }^{12}$ however without the presentation of such an alarming metabolic response to the trauma as in our patient.

In diagnosis, a detailed medical history and a proper physical examination are of vital importance, as well as imaging studies to evaluate bone structures (lysis in vertebral bodies, irregularities in the levels, lordosis or kyphosis angles) and soft tissues, such as a full spinal MRI (reveals the presence of medullary lesions, such as peridural abscesses at one or several locations) and/or gammagraphy. The presence of cervicalgia and neurological symptoms justifies an MRI.

Once the diagnosis is established, surgical cleansing and stabilization of the cervical spine through instrumentation may or may not be performed during the same surgical time. However, the literature reports that, even without instrumentation, stabilization can be achieved once the infection is resolved due to the bone healing process, that allows bone fusion between the affected segments, as was the case in this patient. The con to this is the surgeon's lack of control over the final post-fusion angle of lordosis.

\section{CONCLUSION}

Microbiological isolation plays a fundamental role in the recovery and quality of life of the patient. The need for instrumentation once the infection is resolved is evaluated with clinical and radiographical parameters that suggest instability. We have presented here a case report of a microorganism that is rare in spondylodiscitis in a cervical location, which is also uncommon.

All authors declare no potential conflict of interest related to this article.

CONTRIBUTION OF THE AUTHORS: Each author made significant individual contributions to this manuscript. MC (0000-0001-8352-9732)* and GG $(0000-0002-2502-1356)^{*}$ were the main contributors, performing the surgeries, writing of the article, developing the intellectual concept, and preparing the project. RC (0000-0002-0486-731X)*, CG (0000-0002-4069-1964)* and RV (0000-0002-7674-2428* performed surgeries, followed-up with patients and compiled the clinical data. KG (0000-0002-9665-8063)* and MP (0000-0003-4386-1946)* conducted the bibliographical research, reviewed the manuscript and contributed to the intellectual concept of the study. ${ }^{*}$ ORCID (Open Researcher and Contributor ID)

\section{REFERENCES}

1. Gouliouris T, Aliyu SN, Brown NM. Spondylodiscitis: update on diagnosis and management J Antimicrob Chemoter. 2010;65(Suppl 3):11-24.

2. Jimenez-Avila JM, Cahueque-Lemus MA, Cobar-Bustamante AE, Bregni-Duraés MC. Vertebral Destruction Syndrome: From Knowledge to Practice. J Spine .2015;490:251.

3. Societé de Pathologie Infectieuse de Langue Français. Recommendations pour la pratique clinique. Spondylodiscites infectieuses primitives, et secondaires à un geste intra-discal, sans mise en place de matériel. Med Mal Infect. 2007:37:554-72.

4. Karadimas EB, Bunger C, Lindblad BE, Hansen ES, Høy K, Helmig P, et al. Spondylodiscitis. A retrospective study of 163 patients. Acta Orthop. 2008;79(5):650-9.

5. Friedman JA, Maher CO, Quast LM, McClelland RL, Ebersold MJ. Spontaneous disc space infections in adults. Surg Neurol. 2002;57(2):81-6.

6. Parkins MD, Gregson DB. Community-acquired Serratia marcescens spinal epidural abscess in a patient without risk factors: case report and review. Can J Infect Dis Med Microbiol. 2008;19(3):250-2
7. Chih-Wei Y, Shun-Neng H, Jhih-Syuan L, Dueng-Yuan H. Serratia Marcescens spinal epidural abscess formation following acupuncture. Intern Med. 2014;53(15):1665-8.

8. Shousha M, Boehm H. Surgical treatment of cervical spondylodiscitis. Spine (Phila Pa 1976). 2012;37(1):E30-6

9. Barrecheguren EG, Barriga A, Barroso JL, Villas C. Espondilodiscitis cervicales. Rev Med Univ Navarra. 2001;45(4):11-8

10. Heyde CE, Brehm H, el Saghir H, Tschoke SK, Kayser R. Surgical treatment of spondylodiscitis in the cervical spine: a minimum 2 year follow up. Eur Spine J. 2006;15(9):1380-7

11. Kulkarni AG, Hee HT. Adjacent level disci tis after anterior cervical disectomy and fusion (ACDF): a case report. Eur Spine J. 2006;15(Supply 5):559-63.

12. Centeno AJ, Abejón A, Moreno JJ, Aznar JJ. Absceso sacroiliaco por Seratia marcescens en paciente inmunocompetente. Enferm Infecc Microbiol Clin. 2005;23(5):327-30 